\title{
Penguatan Jaringan Komunikasi LDK (Strategi Pemberdayaan Potensi Keberagamaan Warga di Banyumanik)
}

\author{
Hasyim Hasanah \\ Universitas Islam Negeri Walisongo Semarang \\ Email : hasyimhasanah_82@yahoo.co.id
}

\begin{abstract}
Abstrct: This paper describes the strengthening of communication network of Community Da'wah Institution $(\mathrm{LDK})$ as a strategy to empower the potential of religious residents in Banyumanik. This potential empowerment is aimed at the emergence of citizens' religious awareness, through the shifting of communication networks that are taking place in Banyumanik. Subjects consisted of four LDKs and one foundation. The method of devotion uses the principle of Participatory Rural Apraisal (PRA) with the Feminist approach. The results of the mentoring activities indicate that there is still a problem of religious awareness among residents in Banyumanik. Indication of religious awareness problem besides value system, indicated by the absence of consistency of behavior. Efforts are made to reduce the problem of religious awareness.
\end{abstract}

Abstrak: Tulisan ini menjelaskan mengenai penguatan jaringan komunikasi Lembaga Dakwah Komunitas (LDK) sebagai strategi pemberdayaan potensi keberagamaan warga di Banyumanik. Pemberdayaan potensi ini diarahkan pada munculnya kesadaran beragama warga, melalui pengutan jaringan komunikasi yang tealah berlangsung di Banyumanik. Subjek dampingan terdiri dari empat LDK dan satu yayasan. Metode pengabdian menggunakan prinsip Partisipatory Rural Apraisal (PRA) dengan pendekatan Feminis. Hasil kegiatan pendampingan menunjukkan bahwa masih terdapat problem kesadaran beragama warga di Banyumanik. Problem kesadaran ditunjukkan dengan masih rendahnya sistem nilai warga. Indikasi problem kesadaran beragama selain sistem nilai, ditunjukkan dengan belum adanya konsistensi perilaku. Upaya yang dilakukan untuk mengurangi problem kesadaran beragama.

Kata Kunci: Penguatan, komunikasi, kesadaran beragama. 


\section{PENDAHULUAN}

Kegiatan pembangunan masyarakat desa maupun kota sampai saat ini masih berorientasi pada pendekatan kelompok. Pendekatan kelompok memungkinkan terbentuknya dinamika psiko-sosio-religius berupa rasa percaya, persahabatan, persaudaraan, dan hubungan pertemanan (Surejo, 2009: 229-230). Hubungan ini selanjutnya dapat diarahkan pada pertukaran pesan yang bersifat dyadic. Leeuwis (2009:55-56) menyebutkan pertukaran pesan dyadic mempengaruhi pikiran dan perilaku, sehingga membentuk tindakan untuk menyebarkan pesan. Hasil penelitian Hasanah (2014:57) membuktikan pertukaran pesan melalui pertemanan, secara positif mengarahkan individu mengembangkan seluruh potensi, menjadi pribadi berkualitas dan membawa pesan pembangunan. Penyampaian pesan dikatakan efektif dan efisien apabila anggotanya mampu membawa inovasi pesan pada setiap kegiatan komunikasi. Hubungan komunikasi ini disebut jaringan komunikasi.

Jarngan komunikasi merupakan deskripsi kegiatan komunikasi interpersonal dengan membawa jaringan pesan. Sistem yang dibangun dalam jaringan komunikasi, berperan mengumpulkan, menampung, mengolah, menganalisis dan menyebarkan informasi pesan Hasanah (2014:57). Informasi pesan didasarkan kebutuhan dasar dan potensi kelompok untuk menghasilkan kekuatan, menghantarkan masyarakat mencapai kesejahteraan, dan kemandirian. Peta jaringan komunikasi pada kelompok membawa tema pengembangan dan pemberdayaan komunitas (Setiana, 2005:10). Pesan pada jaringan komunikasi mempengaruhi dan selanjutnya melahirkan perubahan perilaku positif (Katz, 2002: 12). Hampir sebagian besar perubahan yang dihasilkan dari jaringan komunikasi membawa inovasi kehidupan, baik dalam bentuk model, perilaku, teknik atau cara, sikap atau sudut pandang tertentu (Sumardjo, dkk, t.th: vii).

Isu mengenai jaringan komunikasi dapat dimanfaatkan sebagai peningkatan kualitas kehidupan manusia, terutama dalam hal beragama. Jaringan komunikasi dalam konteks ini mengarah pada terjadinya perubah perilaku keagamaan, memunculkan kesadaran dan kemandirian melaksanakan ajaran agama secara konsisten. Proses perubahan perilaku dalam jaringan komunikasi dibentuk dari adanya "klik" pesan. Klik pesan memungkinkan peran pemuka pendapat. Pemuka pendapat menjadi media dan penyampai pesan, memberikan arahan, bimbingan, penyuluhan, serta pendampingan secara intensif, menjadi motor penggerak dan dinamisator untuk memunculkan ibda' bi an nafs (Aliyudin, dan Enjang As, 2009: 23).

Pada jaringan komunikasi lembaga dakwah komunitas (LDK), pemuka pendapat sangat menentukan keberhasilan pendampingan. Ini terbukti dari hasil 
pengabdian tahab ke tiga yang telah dilaksanakan pada tahun 2015. Hasanah (2015) menyebutkan bahwa pemuka pendapat tidak hanya menjadi motor penggerak penyampaian pesan informasi keagamaan, tetapi juga memungkinkan terbentuknya difusi inovasi pesan, sehingga warga urban di wilayah Banyumanik cenderung memunculkan kembali potensi keberagamaan. Hasil pola jaringan komunikasi LDK warga urban di wilayah Banyumanik mendorong lahirnya yayasan Al Hikmah. Yayasan ini diinisisasi beberapa pemuka pendapat LDK (LDK Al Hikmah, LDK Nurul Falah, LDK Nurul Jannah Al Firdaus, LDK Al Huda, dan LDK Al Ikhlas). Kehadiran pemuka pendapat dalam sistem jaringan komunikasi ini terbukti telah dapat memfasilitasi peningkatan potensi keberagamaan berupa kesadaran beragama dan motivasional. Kesadaran beragama melahirkan kesadaran baru dalam berinfak bagi anak yatim dan dhuafa yang dilakukan setiap bulan minggu ketiga. Sedangkan potensi motivasional berupa semangat dan kemauan memaksimakan peran yayasan Al Hikmah, yaitu melalui penguatan TPQ, Perpustakaan, dan fasilitas ambulance di yayasan Al Hikmah.

Keberhasilan program tahap ketiga (tahun 2015) dalam meningkatkan potensi keberagamaan warga urban di Banyumanik melalui jaringan komunikasi, ternyata tidak diimbangi dengan kualitas pengelolaan jaringan komunikasi LDK. Permasalahan baru, dari pola jaringan komunikasi adalah ketidaksolidan kepengelolaan LDK. Masing-masing LDK masih menonjolkan egoisitas kelompok sehingga melahirkan gap dalam melaksanakan pendampingan potensi keberagamaan warga urban. Kondisi ini perlu segera ditemukan upaya solutifnya. Corten (1987) menyebutkan bahwa persoalan dalam jaringan komunikasi menjadi hal yang penting untuk segera dipecahkan, mengingat jaringan komunikasi memiliki kontribusi dalam mengarahkan kualitas komunitasnya menjadi lebih baik, mandiri, dan dengan kemampuannya sendiri mampu mengkreasikan pesan dan membawa tema difusi inovasi pesan pembangunan. Pandangan sama dikemukakan oleh Leeuwis (2009), Setiana (2005:), dan Sumardjo (2010) yang menyebutkan bahwa jaringan komunikasi berkontribusi positif dalam meningkatkan kualitas pelaku komunikasi, pengembangan SDM warga masyarakat, inovasi informasi yang berlangsung cepat dan tepat sasaran dalam meningkatkan hajat hidup komunitas tertentu.

Mendasarkan pada pentingnya jaringan komunikasi pada komunitas, maka kehadiran proyek ini merupakan salah satu bentuk program pendampingan lanjutan (memasuki tahap keempat dari lima tahap yang telah direncanakan) mendasarkan prinsip sustainability, bertujuan secara umum untuk merealisasikan kebutuhan (basic need), sebagai bentuk hajat eksistensial manusia yang 
memerlukan pendampingan dan perbaikan menuju titik kesempurnaan, sekaligus modal dasar perjuangan dakwah Islam. Penulis dalam hal ini berupaya merencanakan proses pengawalan pelaksanaan kegiatan sosial keagamaan LDK masjid dan komunitas urban di wilayah Banyumanik melalui penguatan jaringan komunikasi LDK. Keberlanjutan program ini sangat penting, mengingat rencana program yang telah disusun dalam lima tahun dan telah terbukti menunjukkan hasil menggembirakan. Hasil pengabdian diharapkan mampu memberikan kontribusi memenuhi hak sosial keagamaan, mewujudkan kualitas kehidupan sesuai dengan tujuan dakwah Islam.

\section{METODE DAN KONSEP DASAR PENGEMBANGAN DAN PEMBERDAYAAN MASYARAKAT}

Agar pembangunan mempunyai hasil berkelanjutan, maka alternatif metode yang relevan adalah metode partisipatoris mendasarkan prinsip Integrited or Holistic Strategy. Program didasarkan keterlibatan aktif masyarakat dan seluruh sumber daya potensial. Berkaitan dengan riset partisipatori, program pengabdian tahun 2016 menggunakan metode Partisipatory Rural Appraisal (PRA) dikombinasikan pendekatan feminis (FiPRA). Prinsip FiPRA dilakukan dengan duduk bersama, mendengar, berbaur sehingga mampu melakukan proses belajar dari kesalahan berbasis pada peran sosial masyarakat dengan daur program (Hadiati: 2005: 31). Daur program melibatkan komponen pokok yang saling berkaitan. Masing-masing komponen memainkan peran penting dalam keberhasilan program. Adapun daur program meliputi kegiatan penjajakan kebutuhan, perencanaan, pelaksanaan, pemantauan, dan evaluasi kegiatan, selanjutnya kembali pada siklus berikutnya.

Paradigma pemberdayan dan pengembngan masyarakat bahwa masyarakat dalam kehidupannya senantiasa berada dalam suatu proses menjadi (becoming being), bukan dalam proses being in statistic state. Filosofis pembangunan inilah yang menitik beratkan bahwa membangun masyarakat bukanlah proses membentuk masayarakat seperti keinginan pihak yang akan membantu. Paradigma pemberdayaan dan pengembangan yang berkembang selanjutnya adalah help people to the help him self. Proses pemberdayaan dan pengembangan secara lebih rinci dapat dilihat dalam lima perpektif. Pertama, upaya pembangunan pemberdayaan dan pengembangan masyarakat harus dilihat sebagai sebuah tatanan sosial di mana manusia secara adil dan terbuka melakukan usaha secara mandiri sebagai perwujudan potensi dan kemampuan untuk memenuhi segala kebutuhannya. Pemberdayaan dan pengembanan 
masyarakat berarti bukanlah sebuah tawaran proyek, melainkan sebuah upaya pembenahan struktur sosial yang mengedepankan aspek keadilan, kesejahteraan, dan kemandirian. Kedua, Pemberdayaan dan pengembangan masyarakat bukanlah proses pemberian dari pihak yang memiliki suatu kepentingan kepada yang tidak memiliki kepentingan, melainkan upaya menumbuhkan semangat kemandirian subyek dampingan. Ketiga, harus dilihat sebagai sebuah pembelajaran sosial (social learning), hal ini dimaksudkan agar masyarakat dapat memiliki kemandirian dan kemampuan dalam memperbaiki kualitas kehidupannya. Soedjatmoko menyebutkan bahwa proses yang sering dilupakan dalam pembangunan adalah social learning, sebagai proses kolektif di mana kehidupan masyarakat tidak sekedar menyiapkan penyesuaian terhadap perubahan sosial, melainkan secara aktif mengarahkan terjadinya perubahana sosial pada terpenuhinya kebutuhan bersama. Keempat, sangat tidak mungkin dilakukan tanpa keterlibatan secara penuh oleh masyarakat. Partisipasi bukan sekedar kehadiran dalam mengikuti kegiatan, malainkan masyarakat dapat berkontribusi secara positif dan efektif dalam setiap tahapan proses pemberdayaan dan pengembangan. Kelima, pemberdayaan dan pengembangan adalah proses yang tidak dapat dipisahkan. Pengembangan tidak akan dicapai kalau masyarakatnya tidak berdaya, pemberdayan tidak akan berkelanjutan kalau masyarakataknya tidak memiliki kualitas perbaikan dan perubahan secara berkelanjutan. Pemberdayaan dan pengembangan harus berjalan bersamaan, sehingga output dan outcomes dapat dicapai secara optimal (Soedjatmoko, 1986: 20). Mudzakir menyebutkan bahwa tidak akan mungkin tuntutan keterlibatan masyarakat dalam program pembangunan dicapai apabila masyarakat tidak memiliki bekal, daya, dan kemampuan yang cukup, begitupula sebaliknya (1986: 12-15). Masyarakat harus diberi kepercayaan penuh, bahwa tanpa keterlibatan aktif dan secara penuh, perbaikan kualitas kehidupan tidak membawa hasil yang maksimal. Mewujudkan people empowerment dan development diawali dengan mengubah paradigma dan cara pandang masyarakat untuk menjadi aktif dan partisipatif (Litereel, 1973: 13). Konsep dasar dakwah yang diajarkan Rasulullah saw adalah mengupayakan membantu masyarakat untuk membantu dirinya sendiri meraih kebahagiaan dan kesejahteraannya. Konsep dakwah Islam tentang pemberdayaan dan pengembangan masyarakat sejatinya lebih diarahkan pada upaya mengaktualisasikan nilai-nilai ajaran Islam. Seluruh komponen harus diaktualiasikan dalam kehidupan sosial kemanusiaan, bukan hanya dipahami sebagai cara penyampaian ajaran secara verbal, non verbal, melainkan sebagai wujud penerapan Islam sebagai agama yang rabmatan lil alamin. Asumsi dasar pemberdayaan dan pengembangan masyarakat memiliki pemahaman bahwa 
dakwah bukan hanya penyampaian pesan diluar dakwah, melainkan pertama, seperangkaat dogma atau ajaran baru yang sama sekali asing bagi masyarakat, maka perlu upaya kreatif dan mandiri dalam memahami kontekstualisasi kehidupan. Kedua, masyarakat bukanlah kelompok yang statis, melainkan bersifat dinamis, dan selalu akan mengalami perumahan dalam bersikap, berperilaku, dan bertindak. Ketiga, dakwah tidak hanya sebagatas pada upaya merumuskan keinginan msyarakat, melainkan usaha membenahi kehiduapan sosial secara bersama, agar penindasan, ketidakadilan, dan kesewenangan tidak hidup di tengah mereka. Keempat, dakwah sebagai social learning dan social engineering, sebuah proses mendapatkan perubahan tatanan kehidupan sosial lebih baik (Aziz, 2009: 17). Prinsip dasar dakwah pemberdayaan dan pengembangan masyarakat melibatkan prinsip kebutuhan, partisipasi, keterpaduan, keberlanjutan, keserasian, dan kemampuan sendiri. Prinsip kebutuhan berarti program dakwah pemberdayaan dan pengembangan didasarkan pada pemenuhan basic needs masyarakat. Prinsip partisipatif menekankan seluruh proses pada keterlibatan aktif masyarakat, mulai dari perencanaan, penggorganisasian, penggerakan, hingga penilaian dan pengembangan. Prinsip kebutuhan ini bertujuan untuk mendorong tumbuhnya perubaahan sikap dan perilaku yang lebih kondusif untuk kemajuan; meningkatkan kualitas partisipatif, dari yang hanya sekedar mendukung, menghadiri, menjadi kontributor program dakwah; dan menyegarkan serta meningkatkan efektivitas fungasi dan peranan pemimpin lokal.

Prinsip keterpaduan mencerminkan adanya upaya memadukan seluruh potensi dan sumber daya yang tersedia di masyarakat. Dalam pengertian ini, dakwah pemberdayaan dan pengembanngan bukanlah proses yang dimonopoli sekelompok orang atau ahli dan organisasi, melainkan siapa saja yang memiliki komitmen dalam mengembangkan komunitas (community development). Prinsip keberlanjutan (sustainable) mendasarkan proses yang berkelanjutan, tidak dibatasi waktu, tenaga, dan ruang. Prinsip keberlanjutan inilah dalam aktivitas dakwah disebut dengan istiqamah dalam mewujudkan kesejahteraan lahir dan batin. Prinsip keserasian, berarti memperhatikan pelaksanaan program dakwah dengan mempertibangkan keserasian antara kebutuhan jasmaniyah dan ruhaniyah. Konsep dakwah mengarah pada bentuk karakteristik ajaran Islam yaitu tawazun. Kebutuhan dunia ditujukan untuk mencapai kebahagiaan duniawiyah, sedangkan kebutuhan spiritual atau ruhaniah ditujukan untuk kebahagiaan batiniah. Setiap individu diharapkan dapat mengarahkan potensi yang dimiliki secara mandiri dengan memperhatikan aspek jasmaniah dan ruhaniah secara seimbang. Prinsip kemandirian atau kemampuan sendiri berarti melaksanakan sseluruh proses 
kegiatan berdasarkan pada kemampuan dan sumber-sumber potensi yang dimiliki oleh masyarakat. Masyarakat dalam hal ini diarahkan agar memiliki kesadaran dan mampu mengenali potensi yang dimiliki, sebagai salah satu strategi pemenuhan kebutuhan hidup secara kelompok. Upaya yang dilakukan dapat berupa dialog, penjajakan kebutuhan atau refleksi potensi diri.

\section{LEMBAGA DAKWAH DAN JARINGAN KOMUNIKASI}

Potensi lembaga dakwah dalam pembangunan umat, secara umum bertujuan mengembangkan dan mentransformasikan nilai-nilai Islam, memajukan, serta melibatkan keikutsertaan atau partisipasi masyarakat Muslim dalam mensukseskan pembangunan nasional menuju pembangunan manusia Indonesia seutuhnya. Potensi lembaga dakwah terdiri dari dua potensi, yaitu potensi individual dan kelompok, baik secara kuantitas maupun kualitas. Potensi LDK berupa etos kerja tinggi mencapai ridha Allah, umat Islam secara kuantitas adalah umat terbanyak, tradisi amal sebagai identitas keberagamaan, dan sistem nilai unggul. Lembaga dakwah pada komunitas tertentu, sesuai dengan visi pembangunan manusia Indonesia adalah merealisasikan terwujudnya kehidupan yang sejahtera lahir batin, berkeadilan sosial secara merata. Posisi inilah yang harus dimainkan para aktivis lembaga dakwah komunitas, dalam bentuk kegiatan syiar/ tabligh, sosialisasi, dan aksi sosial. Kegiatan syiar/ tabligh memiliki fokus cakupan kegiatan pada upaya penyebar luasan pesan keislaman. Aksi sosial merupakan wujud dakwah bil haal melalui kegiatan sosial keagamaan dengan tujuan merealisasikan Islam rabmatan lil alamin. Lembaga dakwah komunitas dalam proses pembangunan selalu melibatkan proses komunikasi multi aarah. Komunikasi ini selanjutnya tumbuh dalam sebuah sistem jaringan yang saling berhubungan satu dengan yang lain. Jaringan komunikasi adalah salah satu proses pertukaran pesan informasi komunikasi dari satu orang ke orang lain, melalui pola jaringan tertentu, bersifat unik dan khas. Jaringan komunikasi biasanya hanya dapat dilakukan melalui komunikasi kelompok kecil. Komunikasi dalam kelompok kecil ialah komunikasi antara seorang dengan orang-orang lain dalam kelompok, berhadapan satu dengan lainnya, sehingga memungkinkan terdapatnya kesempatan bagi setiap orang untuk memberikan respon secara verbal.

Robert F. Bales dalam Pranoto (2000) memberikan pengertian atau definisi komunikasi dalam kelompok kecil, sebagai proses pertukaran pesan oleh sejumlah orang yang terlibat dalam interaksi satu sama lain dalam suatu pertemuan yang bersifat tatap muka, dimana setiap partisipan mendapat kesan atau peningkatan hubungan antara satu sama lainnya yang cukup jelas (2000: 9). 
Sehingga ia, baik pada saat timbulnya pertanyaan maupun sesudahnya, dapat memberikan respon kepada masing-masing sebagai perorangan. Sama seperti komunikasi secara umum, komunikasi dalam kelompok kecil juga ditujukan untuk tercapainya suatu kesamaan makna diantara pihak-pihak yang berkomunikasi.

Jaringan komunikasi dapat digambarkan seperti pemahaman "how say to whom" (siapa berbicara kepada siapa) dalam suatu sistem sosial dan kondisi tertentu. Jaringan komunikasi menggambarkan komunikasi bersifat interpersonal. Komunikasi interpersonal di dalamnya terdapat pemuka-pemuka opini dan pengikut yang saling memiliki hubungan komunikasi pada suatu topik tertentu. Komunikasi ini terjadi dalam suatu sistem sosial tertentu seperti sebuah desa, sebuah organisasi, ataupun sebuah perusahaan (Gonzales, 1993: 331). Pengertian jaringan komunikasi menurut Rogers (1981: 324) merupakan sebuah pola jaringan terdiri dari individu-individu yang saling berhubungan, dihubungkan oleh arus komunikasi melalui terpola. Knoke dan Kuklinski (1982) memahami jaringan komunikasi sebagai suatu jenis hubungan yang di dalamnya terdapat pola secara khusus menghubungkan individu-individu, obyek-obyek, dan peristiwa-peristiwa khusus dan spesifik. Sementara itu Farace dalam Berberg dan Knoke (1987) mengartikan jaringan komunikasi sebagai suatu pola teratur dari kontak-kontak antara person yang diidentifikasi sebagai pertukaran informasi dalam sistem sosialnya.

Dari berbagai pengertian tersebut di atas, jaringan komunikasi memurut pemahaman penulis diartikan sebagai sebuah rangkaian hubungan diantara individu sebagai akibat terjadinya pertukaran informasi pesan komunikasi, sehingga membentuk pola-pola atau model-model jaringan komunikasi tertentu.

Pola jaringan komunikasi yang terbentuk akan menghubungkan satu orang dengan orang lainnya. Jaringan komunikasi mengarahkan seseorang untuk merubah perilaku dan sikap sesuai dengan harapan kelompoknya. Dalam suatu jaringan komunikasi, biasanya terdapat seorang pemuka pendapat. Pemuka pendapat sering disebut pimpinan opini atau opinion leader, yaitu orang yang mempengaruhi orang-orang lain secara teratur pada isu-isu tertentu.

Pemuka pendapat memiliki karakteristik yang sangat bervariasi. Perbedaan karakter ini dapat dilihat menurut tipe kelompok yang mereka pengaruhi. Jika pemuka opini terdapat dalam kelompok-kelompok yang bersifat inovatif, maka mereka biasanya lebih bersifat inovatif, meskipun pemuka opini seringkali bukan termasuk inovator yang pertama kali menerapkan inovasi. Di pihak lain, pemuka pendapat dari kelompok-kelompok yang konservatif, biasanya juga bersikap agak konservatif. 
Pada sebagian proses jaringan komunikasi sering melibatkan proses difusi. Difusi yaitu proses masuknya inovasi dalam suatu kelompok sehingga terjadi perubahan perilaku. Difusi dapat terjadi apabila pemuka pendapat memeiliki kemampuan untuk menyokong dan mengendalikan informasi, sehingga berdampak pada terjadinya perubahan perilaku dari orang yang dipengaruhinya. Akan tetapi, pada bebeharapa kasus tertentu pemuka-pemuka opini menentang pengadopsian suatu inovasi. Hal ini dimaksudkan agar, proses komunikasi yang terjadi dalam sebuah jaringan komunikasi bersifat alamiah dan terhindar dari interfensi pemuka pendapat.

Pada tahap berlangsungnya proses jaringan komunikasi, terjadi proses komunikasi dua arah dan interaktif diantara partisipan-partisipan yang terlibat. Berlo (1960: 68) menyebut bahwa partisipan-parsitisipan komunikasi sebagai transciever, karena keduanya mengirim dan menerima pesan-pesan secara timbal balik. Jadi tidak hanya menjalankan satu fungsi sebagai penerima atau pengirim pesan secara pasif. Lebih lanjut dijelaskan bahwa proses komunikasi yang terjadi dalam jaringan komunikasi menggunakan model konvergen yang dicirikan sebagai berikut:

1. Sebuah informasi bisa mengandung beberapa pengertian, dan pengertian ini tergantung pada konteksnya, dan untuk mengambil pengertian tergantung pada "frame of reference".

2. Terjadi kesamaan makna informasi antara komunikator dan komunikan, sebagai tujuan utama berkomunikasi.

3. Hubungan interaktif antara komunikator dengan komunikan menggunakan saluran sistem jaringan komunikasi, yaitu saluran yang digunakan untuk menyampaikan pesan dari satu orang kepada orang lain.

Dari pemahaman di atas dapat disimpulkan bahwa proses komunikasi dalam sistem jaringan terjadi bila ada kesamaan pengertian informasi dari pelaku-pelaku yang saling berkomunikasi, menggunakan pola atau model jaringan komunikasi yang menghubungkan individu dengan inidividu, atau individu dengan kelompok. Proses komunikasi dalam jaringan digunakan untuk menciptakan kebersamaan, memunculkan "mutual understanding", dan persetujuan sama, sehingga ada pemahaman, kesadaran dan selanjutnya terbentuk tindakan dan perilaku yang sama pula (yang melandasi jaringan komunikasi).

\section{HASIL PENGUATAN JARINGAN KOMUNIKASI LDK}

Terdapat dua orientasi dari program pengabdian, yaitu mengidentifikasi problem kesadaran beragama warga urban di banyumanik, dan mengidentifikasi problem serta upaya penguatan jaringan komunikasi lembaga dakwah 
komunitas. Dua problem ini penting untuk dipetakan, mengingat pembangunan di Indonesia sampai saat ini masih mendasarkan prinsip pendekatan kelompok melalui proses komunikasi dalam jaringan. Untuk menemukan problematika tersebut maka diupayakan melalui karya pengabdian dosen (KPD).

Karya pengabdian dosen (KPD), menjadi hal penting dan terobosan baru menuju peradaban dan pengembangan keilmuan di lingkungan perguruan tinggi Islam negeri terutama Universitas Islam Negeri walisongo yang baru beralih status dari Institut Agama Islam Negeri (IAIN) menjadi UIN. Posisional program KPD ditujukan sebagai wujud eksistensi dan kepedulian perguruan tinggi dalam menggandeng mitra atau umat untuk mencapai kesadaran dan kemandirian dalam mewujudkan tujuan kehidupan yang selamat, lahir batin, dan sejahtera adil, dan merata (Hasyim, 2003: 474). Program ini didesain secara berkelanjutan sesuai dengan prinsip dasar program pengembangan masyarakat. Program karya pengabdian dosen selanjutnya memiliki tujuan, manfaat, dan kerangka pemecahan masalah yang didesain sesuai informasi dan basic need komunitas masyarakat dampingan. Pelaksanakaan kegiatan didasarkan pada daur program meliputi penjajakan kebutuhan, perencanaan, pelaksanaan, monitoring, evaluasi dan seterusnya. Sebelum membahas mengenai kanisme KPD, terlebih dahulu akan dijelaskan mengenai problem kesadaran beragama yang dialami oleh warga di Banyumanik.

\section{PROBLEM KESADARAN BERAGAMA WARGA URBAN DI BANYUMANIK}

Tingkat kesadaran beragama seseorang dapat dilihat dari tiga aspek, yaitu sistem nilai, sikap dan cara pandang, dan konsistensi perilaku. Seseorang dengan sistem nilai yang kuat cenderung selalu melakukan internalisasi nilai-nilai ajaran agama yang diyakininya benar. Sistem nilai yang tinggi ditandai dengan kemampuan untuk selalu berpikiran positif, menjalankan ibadah agama, menjalin hungan yang baik dengan orang lain, bersikap terbuka, menerima perbedaan, memiliki keyakinan yang tinggi. Seseorang dengan kesadaran beragama tinggi juga ditunjukkan dengan sikap dan cara pandang positif. Artinya segala bentuk pemikiran, ide berupa ide positif, memnadang orang lain dengan positif, mau menerimma dan menghargai perbedaan, optimis dalam hidup, selalu meningkatkan ketakwaan dan rasa syukur kepada tuhannya. Aspek ketiga adalah konsistensi perilaku. Seseorang dengan kesadaran bergama tinggi dinilai dari perilaku yang selalu konsisten. Memiliki akhak yang baik, apa yang dikatakan 
sesuai dengan apa yang dikejakan, mau menolong orang lain, selalu berbuat amar ma"ruf nahi mungkar, dan lain sebagainya.

Problem kesadaran beragam yang dialami oleh sebagian besar warga di Banyumanik diantaranya pada aspek sistem nilai yang masih rendah, cara pandang dan sikap positif, dan perilaku yang belum konsisten. Problem sistem nilai ini ditunjukkan dengan adanya ketidakmampuan warga menghadirkan nilainilai aajaran agama dalam berbagai sendi kehidupan. Masih banyak warga yang kurang memahami ajaran agama, kurang taat peraturan seperti masih malas melaksanakan ibadah shalat fardhu, belum sepenuhnya menjalankan rukun islam dan iman, kurangnya kepedulian terhadap sesama. Problem konsistensi perilaku ditunjukkan dengan perilaku konsumtif, saling mementingkan komunitasnya, sehingga melahirkan GAP antar kelompok, sikap dan perilaku saling berlawanan sehingga menimbulkan prasangka dan ketegangan.

Problem kesadaran beragama pada sebagina besar warga di Banyumanik disebabkan karena persoalan pemahaman dan pemenuhan kebutuhan (Hasanah, 2016:106). Probem pemahaman mengarah pada bagaimana memahami nilai-nilai yang diajarkan oleh agama. Warga cenderung memiliki disorientasi pada ajaran agama. Ini ditunjukkan dengan kesalahan memahami relasi kemanusiaan, memahami idiologi dan keyakinan. Ada anggapan keliru mengenai kelompok sosial agama. Keyakinan yang dibangun berdasar atas pada kekeliruan pemahaman, mengakibatkan terjadinya konflik antar LDK, muncul gap-gap antar anggota LDK. Persoalan pemahaman lainnya terkait dengan pengetahuan mengenai materi ajaran islam. Dalam hal ini terkait dengan bagaimana warga memiliki wawasan pengetahuan yang luas terkait dengan ajaran agamanya (Hasanah, 2016: 108). Problem lainnya mengenai pemahaman kebutuhan yang keliru. Awalnya pemahaman kebutuhan berupa bagaimana mendapatkan pelayanan sosial keagamaan. Setelah pelayanan sosial keagamaan terpenuhi, justru warga memiliki disorientasi pada pemenuhan kebutuhan. Jaringan komunikasi yang awalnya dimanfaatkan untuk memenuhi kebutuhan akan ajaran islam, berubah menjadi pemenuhan kebutuhan-kebutuhan material. Kegiatan pengajian, bimbingan dan jaringan komunikasi justru digunakan sebagai media untuk mendapatkan informasi-informasi yang bersifat konsumtif, bukan kebutuhan primer. Kekeliruan pemahaman terhadap pemenuhan kebutuhan ini, mengakibatkan warga cenderung menjadi konsumtif dan lebih memikirkan urusan dunia dibandingkan dengan tujuan awalnya untuk mendapatkan bimbingan dan materi ajara islam. Mendasarkan pada hal tersebut, maka melalui program karya pengabdian dosen, berupaya mengurangi problem kesadaran beragama warga masyarakat melalui penguatan jaringan komunikasi. 


\section{PROBLEM JARINGAN KOMUNIKASI}

Beberapa model jaringan komunikasi diyakini memiliki tingkat efektifitas dan efisiensi yang tinggi dalam mengurangi problem sosial di masyarakat. Pertimbangan ini didasarkan pada pola hubungan simbiosis yang terjadi dalam sebuaj pola jaringan komunikasi interpersonal yang dijalankan oleh komunitas tertentu. Pesan informasi dapat berjalan secara cepat, menyebar secara luas dan diterima oleh semua anggota yang tergabung dalam jaringan komunikasi. Namun tidak semua jaringan komunikasi berjalan dengan baik, banyak kendala yang dihadapi dalam membangun komitmen yang tinggi mengenai pola jaringan yang terdiri dari komunitas yang beragam dan berbeda. Pada implementasi proses jaringan komunikasi warga urban di Banyumanik awalnya berjalan dengan baik, sehingga potensi keberagaaan warga meningkat. Namun pada perjalannya ditemukan bahwa terjadi beberapa problem jaringan, diantaranya Jaringan komunikasi para anggota LDK justru terpusat di LDK tertentu, terjadi kebingungan warga dalam memperoleh informasi pesan pembangunan, pesan keagamaan dan pengembangan potensi keagamaan; kebanyakan pola jaringan komunikasi dimanfaatkan pada pemenuhan kebutuhan material, bukan sosial keagamaan; lahirnya gap antar LDK; dan rendahnya kompetensi dan profesionalitas sumber daya manusia LDK (Hasanah, 2016: 78).

Terpusatnya jaringan komunikasi pada LDK tertentu membawa implikasi bahwa pesan pembangunan juga hanya akan dinikmati oleh kelompok tertentu. Jaringan komunikasi juga tidak dapat digunakan untuk meningkatkan potensi komunitas. Terjadinya pemusatan jaringan komunikasi di komunitas tertentu berdampak pada lambatnya proses penyebaran pesan. Pandangan ini dikuatkan oleh Leeuwis yang menyebutkan bahwa penyebaran pesan cenderung terhambat karena adanya pemusatan pesan. Padahal dalam jaringan komunikasi kunci kesuksesan pembangunan terletak pada pesan yang dapat dipancarkan dan didesiminasikan keberbagai kelopok komunitas. Pesan juga harus didifusikan untuk selanjutnya dapat melahirkan inovasi pesan pembangunan.

Problem jaringan komunikasi di wilayah Banyumanik juga berupa kebingungan pemahaman warga. Problem ini hadir karena masing-masing LDK kurang mampu menjalin komunikasi interpersonal yang bersifat timbale balik dan multi arah. Pesan cenderung hanya dinikmati golongan tertentu dan dimanfaatkan untuk kepentingan tertentu pula. Idealnya pesan dalam jaringan komunikasi dapat dimafaatkan bersama, dari, oleh, dan untuk komunitas. Kebingungan warga terjadi karena pesan masing-masing kelompok berbeda. Dalam komponen jaringan komunikasi persoalan ini terjadi karena tidak 
berfungsinya pesan opinion leader, bridge dan kosmopolite. Maing-masing lembaga dakwah harus memiliki opinion leader (pemuka pendapat). Ini dimaksudkan agar pesan yang dikirimkan dapat dikomunikasikan oleh orang yang tepat dan memiliki pengaruh dalam komunitas. Konteks ini memiliki peran bahwa opinion leader adalah orang yang memimpin opini komunitas. Apabila dalam system jaringan tidak memiliki opinion leader, maka pesan pembangunan tidak dapat dipahami oleh komunitas, mengingat komunitas memiliki keunikan masing-masing. Selain opinion leader, peran lain yang juga memiliki kontribusi dalam membawa pesan adalah peran para penghubung (bridge). Penghubung ini berfungsi untuk menghubungkan dua orang atau kelompok yang bukan dalam satu anggota. Kedudukan bridge sangat penting karena di wilayah Banyumanik terdiri dari kelompok-kelompok sosial yang memiliki karakter berbeda, dan asal daerah yang berbeda pula. Bridge dalam hal ini harus mampu menjadi konektor atau penyambung komunikasi pesan informasi. Kosmopolit merupakan bagian lain dalam system jaringan yang memiliki peran seperti bridge. Kosmopolit menjadi penanda hubungan dalam komunikasi kelompok. Apabila anggota kelompok bermain secara aktif maka kedudukan kosmopolit menjadi lebih mudah, sebaliknya apabila masing-masing anggota bersifat pasif maka tugas kosmopolit semakin susah dalam menghubungkan pesan antar anggota.

Problem lainnya berkaitan dengan pemanfaatan jaringan komunikasi pada pemenuhan kebutuhan material, bukan sosial keagamaan. Warga justru memanfaatkan jaringan komunikasi untuk kepentingan material. Warga mulai menjadi komunitas konsumtif, lebih memperhatikan penampilan fashion, kekayaan, dan dipergunakan untuk mengakses hal-hal yang bersifat keduniaan. Warga mulai lupa dengan tujuan utama dibangunnya jaringan komunikasi. Terjadi disorientasi peran jaringan komunikasi yang justru menghambat perkembangan potensi keberagamaan. Jaringan komunikasi pada beberapa komunitas justru melahirnya gap antar LDK. Masing-masing LDK mengklaim bahwa komunitas LDKnyalah yang paling baik, sehingga muncul konflik bersifat horizontal. Timbul rasa kebencian, rasa tidak senang, dan cenderung menganngap LDKnya palng hebat. Gap antar LDK berdampak pada terbangunnya isolate (komunitas terisolasi) sehingga pembangunan tidak tercapai dengan baik.

Problem lain berkaitan dengan rendahnya kompetensi dan profesionalitas sumber daya manusia LDK. SDM yang kurang mumpuni cenderung mempengaruhi jalannya organiasasi. LDK cenderung asal jalan, dengan program yang asal jalan. Hal ini berakibat pada kinerja LDk yang tidak produktif. Banyak faktor yang menyebabkan rendahnya kompetensi dan profesionalitas SDM, yaitu 
faktor yang bersifat internal maupun eksternal. Faktor bersifat internal ersal dari dalam LDK, seperti memilih kepengurusan tidak didasarkan pada kompetensi elainkan atas dasar suka, sistem penempatan SDM berdasarkan kedekatan. Faktor bersifat eksternal diduga berasal dari luar seperti lingkungan. Lingkungan yang tidak kondusif cenderung menyulut persoalan dan konflik, sehingga SDM tidak dapat berkembang secara optimal (Hasanah, 2016: 78). Problem kesadaran beragama dan jaringan komunikasi harus segera diminimalisir dengan pengutan jaringan komunikasi.

Penguatan jaringan komunikasi didasarkan pada prinsip komunikasi interpersonal melibatkan pendekatan kelompok. Pendekatan kelompok mendasarkan prinsip bahwa kelompok memainkan peran strategisnya dalam membangun dinamika psikologis berupa persahabatan, pertemanan dan kekerabatan. Dalam kondisi ini memungkinkan para warga saling melakukan adopsi informasi pesan, sehingga potensi kesadaran beragama dapat dioptimalkan dan diberdayakan. Penguatan jaringan komunikasi dapat dilakukan dengan mendasarkan peran system jaringan komunikasi komunitas. Mendasarkan model sosiometri, maka pengutan jaringan komunikasi dapat diperoleh melalui optimalisisi peran opinion leader, liaison officer, gatekeeper, kosmopilite, dan bridge. Penguatan pada peran opinion leader dapat dilihat dari keberadaan pemuka pendapat. Berdasarkan pada kegiatan pendampingan masing-masing LDK harus memiliki seorang opinion leader. Opinion leader dapat dimanfaatkan sebagai sumber informasi dan pembawa pesan. Masingmasing opinion leader menjadi komunikator, sehingga memungkinkan pesan yang dibawa memiliki sumber dan materi yang sama. Menguatkan peran liaison officer, dimaksudkan agar masing-masing anggota kelompok memiliki penghubung pesan. Kedudukan lision officer ini jaringan komunikasi menghasilkan komunikasi yang efektif. Keberadaan gatekeeper dapat dimanfaatkan untuk menyaring pesan informasi yang masuk dalam kelompok. Geetkeper memungkinkan ada anggota yang memiliki potensi dan kompetensi menyaring informasi sebelum didiseminasi ke masyarakat. Keberadaan geetkeper menjadi penting karena tidak semua pesan memiliki pesan pembangunan, sehingga perlu ada penyaringan pesan. Keberadaan kosmopilite dan bridge dalam jaringan komunikasi memainkan peran sebagai penghubung antar anggota atau kelompok. Dalam hal ini penghubung atau konektor dalam kelompok menggunakan dua model yaitu model circle dan all channel. Mengoptimalkan model Circle Structure dalam jaringan komunikasi menjadikan masing-masing anggota memiliki wewenang atau kekuatan yang sama untuk mempengaruhi kelompok. Memungkinkan semua anggota bisa melakukan interaksi. All Chennel 
structure memungkinkan setiap orang berkomunikasi dengan setiap orang lainnya. Struktur komunikasi yang desentralisasi dirasa efektif untuk pemecahan masalah secara kreatif, dan pergerakan informasi terjadi secara cepat.

Penguatan jaringan komunikasi pada bentuk dan model system jaringan tersebut memungkinkan semua anggota kelompok saling bertukar pikiran, dan timbul kepercayaan. Apabila dalam kelompk telah memiliki rasa kepercayaan, maka sudah barang tentu melahirkan dinamika psikologis berupa rasa persahabatan, saling memiliki dan melindungi. Tema-tema motivasional dan kesadaran dapat diupayakan di melalui penguatan system jaringan komunikasi secara efektif dan efisien.

\section{KESIMPULAN}

Program pengabdian menghasilkan temuan bahwa terjadi problem kesadaran beragama pada warga berupa internalisasi nilai keislam yang masih rendah, konsistensi perilaku dan cara pandang atau sikap negatif. Selain problem kesadaran, program pengabdian juga mampu mengidentifikasi problem jaringan komunikasi berupa terpusatnya kegiatan di LDK tertentu, terjadi kebingungan warga dalam memperoleh informasi pesan pembangunan, pesan keagamaan dan pengembangan potensi keagamaan; kebanyakan pola jaringan komunikasi dimanfaatkan pada pemenuhan kebutuhan material, bukan sosial keagamaan; lahirnya gap antar LDK; dan rendahnya kompetensi dan profesionalitas sumber daya manusia LDK. Usaha yang dapat digunakan untuk mengurangi problem tersebut dilakukan melalui penguatan jaringan komunikasi melalui bentuk dan model jaringan komunikasi. Penguatan jaringan komunikasi diprioritaskan pada peran pimpinan pendapat (opinion leader), liaison officer, gatekeeper, kosmopolite, dan bridge.

Dua model struktur jaringan komunikasi yang dapat dimanfaatkan sebagai strategi peningkatan kesadaran beragama, yaitu circle structure dan All Channel structure. Model jaringan circle structure memungkinkan anggota memiliki wewenang atau kekuatan yang sama untuk mempengaruhi kelompok. Model jaringan All Channel structure memungkinkan semua anggota bisa melakukan interaksi. Setiap orang berkomunikasi dengan setiap orang lainnya. Struktur komunikasi yang desentralisasi. Dirasa efektif untuk pemecahan masalah secara kreatif, dan pergerakan informasi terjadi secara cepat. 


\section{DAFTAR PUSTAKA}

Aliyudin, dan Enjang As., Dasar-Dasar Ilmu Dakwah, Bandung: Widyapadjajaran, 2009

Aziz, Moh. Ali, Dakwah Pemberdayaan Masyarakat: Paradigma aksi Metodologi, Yogyakarta: LKiS, 2009

Bales, Robert F., dalam Juni Pranoto, Pengembangan Potensi Diri, Modul SPAMA, Jakarta: LAN, 2000

Berlo, David K., The Process of Communication An Intriduction to Theory and Practice, New York: Holt, Rinehart and Winston Inc., 1960

Gonzale, Hernando, Beberapa Mitos Komunikasi dan Pembangunan, Dalam A. Jahi (Penyunting), 1993, Komunikasi Massa dan Pembangunan Pedesaan di Negara-negara Dunia Ketiga Suatu Pengantar, Jakarta: PT Gramedia, 1993

Hadiati, Sri, dkk. , Perencanaan SDM: Pendekatan Praktis Perencanaan SDM, Jakarta: LAN RI, 2005

Hasanah, Hasyim, Peran Strategis Aktivis Perempuan Nurul Jannah Al Firdaus dalam Membentuk Kesadaran Beragama Perempuan Miskin Kota, Jurnal Inferensi, Vol. 7, No. 2, STAIN Salatiga, 2013

Hasanah, Hasyim, After Care Service Pasca Pengutan Menejemen LDK Masjid Perumahan dalam membangun Motivasi Spiritual dan Kesadaran Beragama Masyarakat, Laporan Karya Pengabdian Dosen, Lembaga Penelitian dan Pengabdian Masayarakat (LPPM) IAIN Walisongo Semarang, 2014

Hasanah, Hasyim, Analisis Difusi Jaringan Komunikasi Lembaga Dakwah Komunitas Masjid Dalam meningkatkan Kesadaran beragama Warga Perumahan, Laporan Penelitian, Fakultas Dakwah dan Komunikasi IAIN Walisongo, 2014

Hasanah, Hasyim, Microguiding dan Jaringan Komunikasi LDK Masjid (Strategi Pemberdayaan Potensi Keberagaman Warga Perumahan), Laporan Pengabdian, LPPM, UIN Walisongo, 2015 
Hasanah, Hasyim, Penguatan Jaringan Komunikasi Lembaga Dakwah Komunitas (Strategi Pemberdayaan Potensi Keberagamaan Warga Urban di Banyumanik), Laporan KPD, LP2M Uin walisongo, 2016

Katz, E., Innovative Approaches to Finanching Extention for Agricultural and Natural Resources Management - Conceptual Conciderations Analysis of Experiences, (terj.), A. Barandun, LBL: Lindau, 2002

Knoke, Chaffee David and James Kulkinskni, Network. Analysis Sistem. London: Sage Publication, 1982

Knoke, Chaffee David, dan Barberg, Network Analysis, London: Sage Publication, 1987

Korten, David C. (ed.), Community Management: Asia Experience and Perspective, (terj.), Conecticut: Kumarian Pers, 1987

Leeuwis, Cees, Komunikasi untuk Inovasi Pedesaan, Yogyakarta: Kanisius, 2009

Litereel, Donald W., The Theory and Practice of Community Development: A Guide for Practitioners, Harmonsorts: Pinguin Books, 1973

Mudzakir, M. Djauzi, Teori dan Praaktik Pengembangan Masyarakat, Surabaya: Usaha Nasional, 1986

Rogers, Everett, and Lawrence D. Kincaid, Communication Network Toward a New Paradigm for Research. New York: The Free Press, 1981

Setiana, Lucie, Teknik Penyuluban dan Pemberdayaan Masyarakat, Bogor: Ghalia Indonesia, 2005

Soedjatmoko, Social Energy as a Development Resource, Community Management, Conecticut: Kumarian Press, 1986

Sumardjo, dkk., Transformasi Model Penyuluban menuju Kemandirian Warga Masyarakat, Bogor: IPB, 2010 
Surejo dalam Moh Ali Aziz, (ed.), Dakwah Pemberdayaan Masyarakat Paradigma Aksi Metodologi, Yogyakarta: LKiS Pelangi Aksara, 2009 